\title{
Mucinous Neoplasms of the Appendix: Our Clinical Experience and Review of the Literature
}

\section{Apendiks Musinöz Neoplazmları: Klinik Deneyimimiz ve Literatürün Gözden Geçirilmesi}

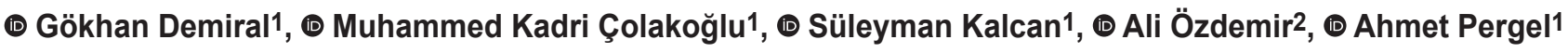 \\ ${ }^{1}$ Recep Tayyip Erdoğan University Faculty of Medicine, Department of General Surgery, Rize, Turkey \\ ${ }^{2}$ Recep Tayyip Erdoğan University Training and Research Hospital, Clinic of General Surgery, Rize, Turkey
}

\section{|IIIIIII| ABSTRACT}

Aim: Neoplastic lesions of the appendix are very rare and most of them are incidentally detected during appendectomy. In this study, we aimed to evaluate the clinicopathological features and applied treatments of the patients who were operated in our clinic and diagnosed as appendiceal mucinous tumor (ApMT) in the light of the literature.

Method: The data and appendectomy specimens of the patients who were operated in our clinic between January 2011 and December 2016 and who were diagnosed as ApMT were retrospectively evaluated. Age, gender, clinical findings, diagnostic methods, histopathological diagnosis and subsequent treatments were evaluated.

Results: Six of the patients were male and four were female. The mean age was 48.6 years (range, 28-85). Nine patients were operated for acute abdomen and one patient was operated electively. Ultrasonography was performed in four patients and computed tomography was performed in six patients preoperatively. Pathological examination revealed simple mucocele in eight patients, mucinous adenoma in one patient and mucinous cystadenoma in one patient. Two patients had appendiceal diverticulum and two patients had diverticulitis associated with acute appendicitis, two patients had appendix perforation and three patients had periapendicular abscess. All patients underwent appendectomy for ApMT.

Conclusion: ApMT is a rare tumor of the appendix that may be benign or malignant. Patients may present with symptoms of acute appendicitis as well as unspecific symptoms. Although preoperative diagnosis is difficult, it helps to minimize complications. Care should be taken to prevent appendix rupture and peritoneal mucus contamination during surgery.

Keywords: Mucocele, appendicitis, appendectomy, pseudomyxoma peritonei

\section{||||||||||| ÖZ}

Amaç: Apendiksin neoplastik lezyonları oldukça nadir görülen ve çoğunluğu apendektomi esnasında insidental olarak saptanan lezyonlardır. Bu çalışmada kliniğimizde opere edilen ve apendiks musinöz tümör (ApMT) tanısı konulan olguların klinikopatolojik olarak incelenerek uygulanan tedavilerin literatür eşliğinde değerlendirilmesi amaçlandı.

Yöntem: Ocak 2011-Aralık 2016 tarihleri arasında kliniğimizde opere edilen ve ApMT tanısı konulan hasta dosyası ve apendektomi piyeslerine ait sonuçlar retrospektif olarak incelendi. Hastaların yaş, cinsiyet, klinik bulgular, tanı yöntemleri, histopatolojik tanı ve sonraki tedavileri değerlendirildi. Bulgular: Hastaların 6'sı erkek, 4'ü kadın olup yaş ortalaması 48,6 (28-85 aralığında) idi. Dokuz hasta akut batın bulguları ile ve 1 hasta elektif olarak opere edilmiş idi. Tanısal yöntem olarak 4 hastada ultrasonografi ve 6 hastada bilgisayarlı tomografi uygulanmış idi. Patolojik değerlendirmede 8 hastada basit mukosel, 1 hastada musinöz adenom ve 1 hastada musinöz kistadenom mevcut idi. İki hastada akut apandisite eşlik eden apandiks divertikülü ve iki hastada divertikülit; iki hastada apendiks perforasyonu; üç hastada ise periapendiküler apse mevcut idi. Tüm hastalarda ApMT için apendektomi işlemi uygulanmış idi.

Sonuç: ApMT apendiksin benign veya malign olabilen nadir bir tümörüdür. Hastalar akut apandisit bulguları yanı sıra belirgin olmayan semptomlar ile başvurabilir. Preoperatif tanı zor olmasına rağmen komplikasyonları en aza indirmede yardımcıdır. Cerrahi esnasında apendiks rüptürünü ve peritoneal mukus kontaminasyonunu önlemek için dikkatli olunmalıdır.

Anahtar Kelimeler: Mukosel, apandisit, apendektomi, psödomiksoma peritonei

Address for Correspondence/Yazışma Adresi: Gökhan Demiral MD,

Recep Tayyip Erdoğan University Faculty of Medicine, Department of General Surgery, Rize, Turkey

Phone: +90 535291939 E-mail: drgokhandemira@@yahoo.com ORCID ID: orcid.org/0000-0003-2807-5437

Received/Gelis Tarihi: 24.11.2018 Accepted/Kabul Tarihi: 07.03.2019

${ }^{\circ}$ Copyright 2019 by Turkish Society of Colon and Rectal Surgery

Turkish Journal of Colorectal Disease published by Galenos Publishing House. 


\section{Introduction}

The neoplastic lesions of the appendix (NLA) are very rare and the majority of them are incidentally noticed during appendectomy. Although NLA are seen at approximately $1 \%$, it is accepted that the rate of unpredictable pathological anomalies is up to $5 \%$, especially due to unexamined lesions. ${ }^{1}$ Appendiceal mucinous tumors (ApMT), also called appendiceal mucocele, are rare NLA and are found incidentally during surgery, routine radiological evaluations or colonoscopic examination. Accumulation of mucoid material within the lumen of the appendix leads to obstructive enlargement of the appendix. ${ }^{2}$ ApMT are more common in women and over the age of 50 , and they constitute $8 \%$ of NLA and $0.3-0.7 \%$ of all appendix pathologies. ${ }^{3,4}$ They have four histopathological subtypes namely simple or retention mucoceles, mucoceles with local or diffuse villous hyperplastic epithelium, mucinous adenoma/cystadenoma and malignant mucinous cystadenocarcinomas. Clinical findings include right lower quadrant pain, palpable mass in the right lower quadrant, colic pain in case of obstruction or invagination, gastrointestinal bleeding, anemia, genitourinary symptoms, acute abdomen, and sepsis in case of rupture of the cyst. Because the findings are nonspecific, they are rarely diagnosed during radiological, sonographic, or endoscopic procedures. ${ }^{3,4}$ On the other hand, most cases are asymptomatic until diagnosis is made intraoperatively or during postoperative histopathological examination. ${ }^{4}$ The recommended treatment for ApMT is surgery and the surgical method should be determined according to tumor size, the presence of local or diffuse peritoneal mucus, appendix perforation, surgical margin status and histological type of tumor. ${ }^{5}$ Appendectomy is sufficient in benign ApMT, and cecum resection or right hemicolectomy is recommended in the presence of spread to neighboring bowel segments, regional lymphadenopathy, pseudomyxoma peritonei (PMP) or malignancy. ${ }^{5}$ In this study, we aimed to evaluate the clinicopathological examination of the patients who were operated in our clinic and diagnosed as ApMT in the light of the literature.

\section{Materials and Methods}

The medical records and the results of appendectomy specimens of ten patients who underwent emergency surgery with the diagnosis of acute appendicitis or elective surgery with other diagnoses in our clinic between January 2011 and December 2016 were retrospectively analyzed. Informed consent was obtained from all patients in the study. Age, gender, clinical findings, diagnostic methods, histopathological diagnoses and subsequent treatments were evaluated.

\section{Results}

Six of the patients were male and four were female. The mean age was 48.6 years (range, 28-85). Physical examination records revealed right lower quadrant pain and direct rebound findings on physical examination in nine patients. One patient was electively operated. Ultrasonography (US) was performed in four patients and computed tomography (CT) was performed in six patients as a diagnostic method, and both diagnostic methods were used in one patient who was operated electively. Pathological examination revealed simple mucocele in eight patients, mucinous adenoma in one patient and mucinous cystadenoma in one patient. One of the patients with simple mucocele was consulted to general surgery clinic due to periapendicular adhesions while undergoing total abdominal hysterectomy + bilateral salpingo-oopherectomy for endometrial adenocarcinoma, and she had appendectomy. The patient with detected mucinous cyst adenoma was operated for acute abdomen and right ovarian hemorrhagic cyst adenoma rupture was detected. Two patients had appendiceal diverticulum and two patients had diverticulitis associated with acute appendicitis, two patients had diverticulitis, two patients had appendix perforation and three patients had periapendicular abscess. Open appendectomy was performed in all patients (Tables 1, 2).

\section{Discussion}

ApMT, which is rarely reported in the literature and is usually incidentally detected, is more common between the ages of 50 and 69 years, although it occurs at any stage of life. ${ }^{6,7}$ Regarding the gender distribution, there are

Table 1. Demographic data of patients

\begin{tabular}{|c|c|}
\hline Mean age (years) & 48.6 (range, 28-85) \\
\hline Gender & $6 \mathrm{M}, 4 \mathrm{~F}$ \\
\hline Type of admission & $\begin{array}{l}\text { Acute abdomen (9) } \\
\text { Elective surgery (1) }\end{array}$ \\
\hline Diagnostic method & $\begin{array}{l}\text { US (4)/CT (6) } \\
\text { CT/US (1) }\end{array}$ \\
\hline Pathological diagnosis & $\begin{array}{l}\text { Simple mucocele (8) } \\
\text { Mucinous adenoma (1) } \\
\text { Mucinous cystadenoma (1) }\end{array}$ \\
\hline $\begin{array}{l}\text { Accompanying } \\
\text { Appendix diverticulum (n) }\end{array}$ & 2 \\
\hline Abscess, perforation & $2 / 2$ \\
\hline Surgical procedure & Appendectomy (10) \\
\hline
\end{tabular}


Table 2. Gender, age, pathologic diagnosis, clinical diagnosis, surgical procedure and accompanying findings of the patients

\begin{tabular}{|c|c|c|c|c|c|c|}
\hline Patient ID & Gender & Age & Pathologic diagnosis & Clinical diagnosis & Surgical procedure & $\begin{array}{l}\text { Accompanying } \\
\text { findings }\end{array}$ \\
\hline 1 & M & 40 & Simple mucocele & Acute appendicitis & Open appendectomy & - \\
\hline 2 & $\mathrm{~F}$ & 70 & Mucinous adenoma & $\begin{array}{l}\text { Perforated } \\
\text { appendicitis }\end{array}$ & Open appendectomy & - \\
\hline 3 & $\mathrm{~F}$ & 85 & Simple mucocele & Acute appendicitis & Open appendectomy & - \\
\hline 4 & M & 62 & Simple mucocele & $\begin{array}{l}\text { Perforated } \\
\text { appendicitis }\end{array}$ & Open appendectomy & $\begin{array}{l}\text { Abscess, } \\
\text { diverticulum }\end{array}$ \\
\hline 5 & M & 60 & Simple mucocele & Acute appendicitis & Open appendectomy & $\begin{array}{l}\text { Abscess, } \\
\text { diverticulitis }\end{array}$ \\
\hline 6 & M & 28 & Simple mucocele & Acute appendicitis & Open appendectomy & $\begin{array}{l}\text { Abscess, } \\
\text { diverticulitis }\end{array}$ \\
\hline 7 & M & 28 & Simple mucocele & Acute appendicitis & Open appendectomy & $\begin{array}{l}\text { Abscess, } \\
\text { diverticulum }\end{array}$ \\
\hline 8 & M & 29 & Simple mucocele & Acute appendicitis & Open appendectomy & - \\
\hline 9 & $\mathrm{~F}$ & 43 & Mucinous cystadenoma & $\begin{array}{l}\text { Hemorrhagic serous } \\
\text { ovarian cystadenoma }\end{array}$ & $\begin{array}{l}\text { Open appendectomy/right } \\
\text { ovarian cyst excision }\end{array}$ & - \\
\hline 10 & $\mathrm{~F}$ & 41 & Simple mucocele & $\begin{array}{l}\text { Endometrial } \\
\text { adenocarcinoma }\end{array}$ & $\begin{array}{l}\text { TAH/BSO/open } \\
\text { appendectomy }\end{array}$ & - \\
\hline
\end{tabular}

inconsistencies in the literature, and some studies report a higher incidence in women, while others report a similar incidence in both genders. ${ }^{5,7}$ In our study, the mean age of the patients was 48.6 years (range, 28-85) and was close to the lower limit of the age range reported in the literature. The male-female ratio was $2 / 3$ and a total of three male patients had simple mucocele detected in 20s. ApMT are divided into 4 pathological types according to their epithelial characteristics:

- Simple or retention mucoceles; they are usually caused by obstruction of the root of the appendix with fecalitis or inflammatory adhesion. It is characterized by normal epithelial structure and slight luminal dilatation up to $1 \mathrm{~cm}$.

- Mucoceles containing local or diffuse villous hyperplastic epithelium; luminal dilatation is mild and constitutes 5-25\% of mucoceles.

- Mucinous adenoma/cystadenoma; is the most common group and constitutes $63-84 \%$ of the cases. This group usually has some degree of epithelial atypia and villous adenomatous changes. There is significant distention in the lumen (up to $6 \mathrm{~cm}$ ). It is benign and does not carry a risk of recurrence.

- Malignant mucinous cystadenocarcinomas; constitute 11$20 \%$ of the cases. Glandular stromal invasion, desmoplastic reaction and/or the presence of epithelial cells in peritoneal implants are observed. Luminal dilatation is very high. ${ }^{8}$
Most patients with ApMT are asymptomatic and may exhibit different clinical findings. ${ }^{9}$ Acute or chronic pain in the right iliac fossa is the most common symptom. Sometimes a palpable mass may be detected on physical examination. ${ }^{4}$ The symptoms observed in the presence of malignant mucocele are weight loss, general condition disorder and presence of intraabdominal masses; however, acute pain in the right iliac fossa is more common in benign mucoceles. ${ }^{6}$ In our study, nine patients showed clinical findings of acute appendicitis at admission and one of them had mucinous cyst adenoma associated with right ovarian cyst rupture. Mucinous cystadenoma is located in the benign part of the pathological spectrum and does not carry a risk of recurrence. Mucinous cystadenocarcinoma with stromal invasion and intraperitoneal spread is similar to ovarian mucinous cystadenocarcinoma with high lymph node involvement and liver metastasis and low survival rate. ${ }^{9}$ In our study, simple mucocele was detected in eight patients, mucinous adenoma in one patient and cyst adenoma in one patient. No mucinous cystadenocarcinoma was detected. One case was operated electively for endometrial adenocarcinoma and concurrent appendiceal simple mucocele was detected. Advances in diagnostic methods, especially in abdominal US and $\mathrm{CT}$, have increased the possibility of preoperative diagnosis of mucoceles. ${ }^{6}$ Cysts of different echogenicities can be identified in relation to the amount of mucus on US. 
Multiple echogenic foci in the dilated appendix may reveal multiple echogenic layers that give the appearance of onionskin layers that may be pathognomonic for the mucocele. ${ }^{10}$ In the US, an appendix with a diameter of 15 $\mathrm{mm}$ and above has a sensitivity of $83 \%$ and a specificity of $92 \%$ for mucocele. ${ }^{11}$ On the other hand, appendiceal mucocele is a round, thin-walled cystic mass with a capsular structure in CT. Calcification is detected in $50 \%$ of the cases and the presence of nodules in the mucocele wall suggests cyst adenocarcinoma. ${ }^{12}$ Malignancy is rarely detected under $2 \mathrm{~cm}$. In addition, cystadenoma/cystadenocarcinoma is detected more frequently in large mucoceles $(6 \mathrm{~cm}$ or more) and a higher rate $(20 \%)$ of perforation is observed..$^{13}$ The presence of acid on CT is a nonspecific finding and may be observed in PMP. Since the mucin-producing cells in PMP are weakly adhesive, they can easily be displaced by peristaltic movements and adhere to immobile areas. Douglas/rectovesical pouch, right and left subphrenic areas, and liver and spleen surfaces are the most common sites. ${ }^{14}$ Colonoscopy should also be performed preoperatively to exclude the presence of colorectal neoplasia in all patients with suspected appendiceal mucocele..$^{15}$ Colonoscopy shows a "volcano sign" in which the appendix orifice is located in the middle of a prominent bump surrounded by a normal mucosa or a yellowish lipoma-like submucosal mass. ${ }^{16}$ Mucosal biopsies are usually reported as normal. ${ }^{15}$ Biochemical tests may also be used in the diagnosis of ApMT. High levels of carcinoembryonic antigen (CEA) may be seen in cystadenocarcinomas, but this antigen is not routinely evaluated in ApMT because the CEA levels in cystadenomas are rarely high. Preoperative evaluation may include tumor markers such as alpha-fetoprotein and carsinoma antigen 19-9 as well as CEA. ${ }^{17}$ In our study, US was performed in four patients and CT was performed in five patients who underwent emergency surgery, and the imaging findings were reported consistent with acute appendicitis. ApMT was not suspected preoperatively in any patients, and therefore colonoscopy was not performed and tumor markers were not examined. Right hemicolectomy is often performed in the treatment of suspected malignancy in preoperative imaging or when malignant mucocele is detected during frozen examination. ${ }^{5}$ Although right hemicolectomy is the standard treatment modality in malignant ApMT, recent studies suggest that the presence of a mucocele with a solid surgical margin is an indicator of good prognosis and disease-free survival. ${ }^{7}$ Gonzalez-Moreno and Sugarbaker ${ }^{18}$ reported in 501 patients with appendiceal epithelial neoplasia that right hemicolectomy was not superior to appendectomy in terms of survival. However, the authors suggested that right hemicolectomy is required in the presence of need for complete excision of a primary tumor or complete cytoreduction, lymph node involvement revealed by histopathological examination of the appendix or ileocolic lymph nodes, and the presence of a nonmucinous neoplasia identified by histopathological examination. The choice of open or laparoscopic surgery in ApMT is controversial. ${ }^{19}$ Laparotomy is the best option if the mass is large and resection is difficult. On the other hand, laparoscopic methods have become popular in the last decade and many authors have suggested that laparoscopic method is a safe choice in ApMT surgery. ${ }^{5}$ However, since the distribution of mucus or epithelial cells in the peritoneal space is associated with poor prognosis, rupture and peritoneal contamination should be avoided. For this purpose, the appendix should be pulled to a minimum during laparoscopy, low levels of pneumoperitonium pressure should be provided and the bag should be used when removing the excised material. ${ }^{5}$ In addition, the presence of any mucinous fluid in the abdomen should be carefully examined. There is consensus that appendectomy is sufficient in the treatment of non-ruptured benign appendix mucoceles..$^{20}$ In our study, all patients underwent open appendectomy. Since no malignancy was reported pathologically, the surgical procedure was satisfactory. Two cases where the appendix was ruptured during surgery were at $26^{\text {th }}$ and $28^{\text {th }}$ months and are still being followed up. Follow-up was not recommended in other cases. PMP occurs only in a small proportion of mucinous neoplasms. It is characterized by peritoneal spread and implant formation due to iatrogenic or spontaneous rupture of mucocele during appendectomy or due to mucinous cystadenoma/ cystadenocarcinoma. ${ }^{5}$ Although clinically more severe, it has a slowly progressive course, often accompanied by nonspecific abdominal symptoms. The most common symptom is acute or chronic pain in the right lower quadrant. ${ }^{21}$ The disease is progressive in both cases when the ruptured primary mass and mucinous cells spreading along the peritoneal surfaces are benign or malignant. Since PMP usually develops as a complication of ovarian and appendix masses, PMP should be suspected in the history of appendectomy. ${ }^{21}$ Although ovaries were considered to be the most common primary organ in the past, recent studies based on immunohistochemical analysis and molecular biology have shown that ovary is a rare source of PMP and that lesions previously called "ovarian borderline mucinous tumors" are typically metastatic lesions of the appendix. ${ }^{21}$ PMP treatment varies due to the rarity of the disease and slow progression of the disease. ${ }^{22}$ Current treatment strategies of PMP include careful monitoring and continuous observation; enlarged cytoreductive surgery alone or with 
hyperthermic intraoperative peritoneal chemotherapy and early postoperative intraperitoneal chemotherapy. ${ }^{19}$ In a study based on Sugarbaker's peritonectomy procedure, cytoreductive surgery with intraperitoneal hyperthermic perfusion allowed complete removal and this combined treatment proved its efficacy in terms of increased long-term survival and better regional control of the disease. ${ }^{23}$ However, other studies support that fluorouracil-based adjuvant systemic chemotherapy should be the standard treatment for appendix-related PMP patients. ${ }^{24}$ When surgery is not required immediately, patients can be monitored with CT scans, tumor markers, laboratory tests and physical symptoms, and the time of surgery can be planned. Since the risk of developing colonic adenocarcinoma in these patients is 6 times higher than in the general population, patients should be followed by colonoscopy. ${ }^{25}$ In addition, screening of solid organs, such as kidney and lung, should be performed in malignant ApMT cases. No PMP was detected in any patient in our study. In conclusion, ApMT is a rare tumor of the appendix that can be benign or malignant. Patients may present with signs of acute appendicitis as well as non-significant symptoms. Although preoperative diagnosis is difficult, it is highly helpful in determining the correct treatment method and minimizing intraoperative and postoperative complications. Ultrasound and CT may be helpful in preoperative diagnosis: however, sometimes it is accompanied by colon cancer and may be detected incidentally during colonoscopy. ApMT treatment is open or laparoscopic appendectomy. Treatment options for malignancy include right hemicolectomy. Since PMP is a feared complication, appendix rupture and peritoneal mucus contamination should be avoided during surgery.

\section{Ethics}

Ethics Committee Approval: The study was approved by the Recep Tayyip Erdoğan University Faculty of Medicine Clinical Research Ethics Committee (approval number: 2019/21).

Informed Consent: Retrospective study.

Peer-review: Internally peer-reviewed.

\section{Authorship Contributions}

Surgical and Medical Practices: G.D., M.K.Ç., A.P., Concept: G.D., S.K., Design: S.K., A.Ö., Data Collection or Processing: M.K.Ç., A.P., Analysis or Interpretation: G.D., A.P., Literature Search: G.D., A.Ö., Writing: G.D.

Conflict of Interest: No conflict of interest was declared by the authors.

Financial Disclosure: The authors declared that this study received no financial support.

\section{References}

1. McCusker ME, Cote TR, Clegg LX, Sobin LH. Primary malignant neoplasms of the appendix: a population-based study from the surveillance, epidemiology and end-results program, 1973-1998. Cancer 2002;94:3307-3312.

2. Demetrashvili Z, Chkhaidze M, Khutsishvili K, Topchishvili G, Javakhishvili T, Pipia I, Qergadze V. Mucocele of the appendix: case report and review of literature. Int Surg 2012;97:266-269.

3. Kim-Fuchs C, Kuruvilla YC, Angst E, Weimann R, Gloor B, Candinas D. Appendiceal mucocele in an elderly patient: how much surgery? Case Rep Gastroenterol 2011;5:516-522.

4. Ruiz-Tovar J, Teruel DG, Castiñeiras VM, Dehesa AS, Quindós PL, Molina EM. Mucocele of the appendix. World J Surg 2007;31:542-548.

5. Singh MK, Kumar MK, Singh R. Laparoscopic appendectomy for mucocele of the appendix. J Nat Sci Biol Med 2014;5:204-206.

6. García Lozano A, Vázquez Tarrago A, Castro García C, Richart Aznar J, Gómez Abril S, Martínez Abad M. Mucocele of the appendix: Presentation of 31 cases. Cir Esp 2010;87:108-112.

7. Misdraji J, Yantiss RK, Graeme-Cook FM, Balis UJ, Young RH. Appendiceal mucinous neoplasms: a clinicopathologic analysis of 107 cases. Am J Surg Pathol 2003;27:1089-1103.

8. Paladino E, Bellantone M, Conway F, Sesti F, Piccione E, Pietropolli A. Large mucocele of the appendix at laparoscopy presenting as an adnexal mass in a postmenopausal woman: a case report. Case Rep Obstet Gynecol 2014;2014:486078.

9. Spyropoulos C, Rentis A, Alexaki E, Triantafillidis JK, Vagianos C. Appendiceal mucocele and pseudomyxoma peritonei; the clinical boundaries of a subtle disease. Am J Case Rep 2014:27:355-360.

10. Caspi B, Cassif E, Auslender R, Herman A, Hagay Z, Appelman Z. The onion skin sign: a specific sonographic marker of appendiceal mucocele. J Ultrasound Med 2004;23:117-121.

11. Lien WC, Huang SP, Chi CL, Liu KL, Lin MT, Lai TI, Appendiceal outer diameter as an indicator for differentiating appendiceal mucocele from appendicitis. Am J Emerg Med 2006;24:801-805.

12. Pickhardt PJ, Levy AD, Rohrmann CA Jr, Kende AI. Primary neoplasms of the appendix: radiologic spectrum of disease with pathologic correlation. Radiographics 2003;23:645-662.

13. Lau H, Yuen WK, Loong F, Lee F. Laparoscopic resection of an appendiceal mucocele. Surg Laparosc Endosc Percutan Tech 2002;12:367-370.

14. Diop AD, Fontarensky M, Montoriol PF, Da Ines D. CT imaging of peritoneal carcinomatosis and its mimics. Diagn Interv Imaging 2014;95:861-872.

15. Zanati SA, Martin JA, Baker JP, Streutker CJ, Marcon NE. Colonoscopic diagnosis of mucocele of the appendix. Gastrointest Endosc 2005;62:452456.

16. Hamilton DL, Stormont JM. The volcano sign of appendiceal mucocele. Gastrointest Endosc 1989;35:453-456.

17. McFarlane ME, Plummer JM, Bonadie K. Mucinous cystadenoma of the appendix presenting with an elevated carcinoembryonic antigen (CEA): Report of two cases and review of the literature. Int J Surg Case Rep 2013;4:886-888.

18. Gonzalez-Moreno S, Sugarbaker PH. Right hemicolectomy does not confer a survival advantage in patients with mucinous carcinoma of the appendix and peritoneal seeding. Br J Surg 2004;91:304-311.

19. Dhage-Ivatury S, Sugarbaker PH. Update on the surgical approach to mucocele of the appendix. J Am Coll Surg 2006;202:680-684.

20. Kılıç MÖ, İnan A, Bozer M. Four mucinous cystadenoma of the appendix treated by different approaches. Ulus Cerrahi Derg 2014;30:97-99.

21. Carr NJ. Current concepts in pseudomyxoma peritonei. Ann Pathol 2014:34:9-13 
22. Buell-Gutbrod R, Gwin K. Pathologic diagnosis, origin, and natural history of pseudomyxoma peritonei. Am Soc Clin Oncol Educ Book 2013:221225

23. Deraco M, Baratti D, Inglese MG, Allaria B, Andreola S, Gavazzi C, Kusamura S. Peritonectomy and intraperitoneal hyperthermic perfusion (IPHP): a strategy that has confirmed its efficacy in patients with pseudomyxoma peritonei. Ann Surg Oncol 2004;11:393-398.
24. Chen CF, Huang CJ, Kang WY, Hsieh JS. Experience with adjuvant chemotherapy for pseudomyxoma peritonei secondary to mucinous adenocarcinoma of the appendix with oxaliplatin/ fluorouracil/leucovorin (FOLFOX4). World J Surg Oncol 2008;6:118.

25. Federle MP, Anne VS. Mucocele of the appendix. In: Federle MP, ed Diagnostic imaging: abdomen. 1st ed. Salt Lake City, Utah: Amirsys Inc. 2004:26-27. 